\title{
Assessment of knowledge, attitude and practice of reporting of adverse drug reaction among family physicians in Surat city
}

\author{
Kirti Saxena $^{1 *}$, Sachendra K. Srivastava ${ }^{1,2}$ \\ ${ }^{1}$ Department of Pharmacology Surat Municipal Institute of Medical Education and Research, Surat, Gujarat, India \\ ${ }^{2}$ Department of Pharmacology, Vedanta Institute of Medical Sciences, Palghar, Maharshtra, India
}

Received: 16 May 2021

Revised: 13 June 2021

Accepted: 14 June 2021

\section{*Correspondence:}

Dr. Kirti Saxena,

Email: saxenadrp@gmail.com

Copyright: (C) the author(s), publisher and licensee Medip Academy. This is an open-access article distributed under the terms of the Creative Commons Attribution Non-Commercial License, which permits unrestricted non-commercial use, distribution, and reproduction in any medium, provided the original work is properly cited.

\begin{abstract}
Background: Majority of the patients first contact the family physicians (FP) for treatment. If adverse drug reaction (ADR) occurs necessary measures are taken and ADR managed but usually not reported. The present study was conducted to assess knowledge, attitude and practice of reporting of ADR among family physicians.

Methods: The study was a prospective cross-sectional questionnaire based study. The correctly filled forms from 90 family physicians were analysed based on 20 questions (knowledge 10, attitude 5, and practice 5).

Results: Majority of family physicians were aware regarding the occurrence of ADR and 59\% of them were aware that all ADR should be reported. Most of $(71 \%)$ the physicians do not know there is ADR reporting form. Majority of them (93\%) are aware that reporting of ADR is necessary that will increase patient safety (92\%). About $78 \%$ of physician were aware that ADR can be reported by any of health care professional. However, about $71 \%$ do not know how to report and where to report ADR. Only few of them (19\%) have reported ADR.

Conclusions: The family physicians of Surat have adequate knowledge about pharmacovigilance and aware that ADR should be reported. However, most of them have not reported any ADR due to various reasons.
\end{abstract}

Keywords: ADR, Pharmacovigilance, Knowledge, Attitude, Practice

\section{INTRODUCTION}

An adverse drug reaction (ADR) defined by WHO as any noxious unintended or undesired effect of a drug that occurs at dose used in humans for prophylaxis, diagnosis or treatment. ${ }^{1}$

ADR are known to be major cause of morbidity and mortality and contribute to substantial burden on health care resources. $^{2}$

Reporting of ADR is an important component of monitoring and the evaluation activities which are performed in the hospital. India rate below $1 \%$ in terms of world rate of $5 \% .^{3}$
Studies are available regarding knowledge, attitude, practice (KAP) in a tertiary care hospital and various other hospitals by health care professional that include clinician, resident doctors, nurses and pharmacists.,

Majority of the patient first contact the family physician for treatment.

If ADR occurs necessary measure are taken and ADR managed but usually ADR are not reported. Whether ADR is reported or not is not clear.

Therefore, we planned to evaluate awareness and reporting of ADR among family physician; moreover, knowledge and attitude of reporting ADR were assessed. 


\section{Aims and objectives}

Aims and objectives were to evaluate reporting of ADR among family physician, to assess the knowledge and attitude of reporting of ADR among family physician.

\section{METHODS}

This was a prospective questionnaire based observational study done in Surat city of India. The clearance from institutional ethical committee was obtained before the study. This study was done from October 2016 to June 2017. After obtaining approval from institutional ethical committee the family physicians of the Surat city contacted and a printed questionnaire-based survey was done after taking informed consent from them. Confidentiality of the information obtained maintained throughout the study at all the levels.

The questionnaire contained 20 questions (knowledge 10, attitude 5, and practice 5) are designed to assess the KAP. Incompletely filled questionnaires are excluded from the study. The responses were analyzed using Microsoft Excel 2010 .

\section{RESULTS}

Questionnaire forms were distributed among 200 family physicians of Surat city. Out of these only 125 forms received back so response rate is $62.5 \%$, and 35 were incompletely filled so excluded from the study and 90 completely filled form were analysed for the study.

About $69 \%$ of doctors gave correct response regarding definition of pharmacovigilance. About $29 \%$ of doctors have never seen ADR reporting form. The doctors aware about three common ADR along with medicine were $74 \%$. The percentage of doctors not aware about drugs banned was $62 \%$. About $59 \%$ of doctors were aware that the regulatory body responsible for monitoring of ADR in India and it is Central Drugs Standard Control Organization (CDSCO).
The international centre for adverse drug reaction monitoring is located in Sweden was correctly mentioned by $40 \%$ doctors. About $59 \%$ of doctors were believed that all unknown and known ADRs should be reported for patient safety.

The sources of information for doctors about ADR were text books $50 \%$, journals $47.7 \%$, medical representatives $17.7 \%$, seminars/conferences $52.2 \%$, and internet $54.4 \%$.

About $78 \%$ of doctors were aware that anyone can report ADR (medical practitioners, nursing staff, dentists, physiotherapists, pharmacists); and $60 \%$ of doctors were aware that the nearest ADR centre is located at Surat Municipal Institute of Medical Education and Research.

Only $47 \%$ of doctors were aware that rare ADRs can be identified during 4th phase of a clinical trial and $93 \%$ of doctors aware that reporting of ADR is necessary. Pharmacovigilance should be taught to the health care professionals were the answer given by $91 \%$ doctors. Most of the doctors (92\%) were aware that reporting of ADR will increase patient safety.

Reasons which discourage doctors from reporting ADRs are $38.8 \%$ lack of time to report ADR, 35.5\% difficult to decide whether ADR has occurred or not, $17.7 \%$ a single unreported case may not affect ADR database, 20\% no remuneration, $18.8 \%$ fear of action against person reporting and $71.11 \%$ don't know where and how to report?

Reporting of ADR is a professional obligation was the belief of $52 \%$ of doctors. Only $19 \%$ of doctors reported ADR to the pharmacovigilance centred their medical practice and $51 \%$ of doctors out of who reported ADR find difficulty in reporting ADR.

Small percentage of doctors (only $16 \%$ ) ever been trained to report an ADR and only $13 \%$ of doctors were aware of any helpline for reporting of ADR.

Table 1: Knowledge related question and percentage of response.

\begin{tabular}{|c|c|c|}
\hline Questions & $\begin{array}{l}\text { Correct } \\
\text { response }(\%)\end{array}$ & $\begin{array}{l}\text { Incorrect } \\
\text { response }(\%)\end{array}$ \\
\hline Definition of pharmacovigilance & 69 & 31 \\
\hline Have ever you saw the ADR reporting form & 29 & 71 \\
\hline List three common ADR along with medicine & 74 & 26 \\
\hline Name any three drugs are banned in last 5 years & 38 & 62 \\
\hline Name of the regulatory body responsible for monitoring of ADR in India & 59 & 41 \\
\hline $\begin{array}{l}\text { Where the international center for adverse drug reaction monitoring is } \\
\text { located? }\end{array}$ & 40 & 60 \\
\hline Which type of ADRs should be reported for patient safety & 58.8 & 41.2 \\
\hline Who can report ADR? & 78 & 22 \\
\hline Where is nearest center for reporting of ADRs & 60 & 40 \\
\hline During which phase of a clinical trial rare ADRs can be identified? & 47 & 53 \\
\hline
\end{tabular}


Table 2: Attitude related question and percentage of response.

\begin{tabular}{|c|c|c|}
\hline Questions & $\begin{array}{l}\text { Correct response } \\
(\%)\end{array}$ & $\begin{array}{l}\text { Incorrect } \\
\text { response }(\%)\end{array}$ \\
\hline Awareness about reporting necessity of ADR & 94 & 6 \\
\hline Need of teaching of pharmacovigilance to the health care professionals & 91 & 9 \\
\hline Will reporting of ADR increase patient safety & 92 & 8 \\
\hline Is reporting of ADR professional obligation & 52 & 48 \\
\hline
\end{tabular}

Table 3: Practice related question and percentage of response.

\begin{tabular}{|lll|}
\hline Questions & $\begin{array}{l}\text { Correct response } \\
(\%)\end{array}$ & $\begin{array}{l}\text { Incorrect } \\
\text { response }(\%)\end{array}$ \\
\hline Have you ever reported ADR to the pharmacovigilance centre? & 19 (yes) & 81 (no) \\
\hline Have you ever been trained about reporting ADR & 17 & 83 \\
\hline Are you aware of any helpline for reporting of ADR & 14 & 86 \\
\hline
\end{tabular}

Table 4: Source of information about ADR.

\begin{tabular}{|ll|}
\hline Source & Percentage \\
\hline Text books & 50 \\
\hline Journals & 47.7 \\
\hline Medical representatives & 17.7 \\
\hline Seminars/conferences & 52.2 \\
\hline Internet & 54.4 \\
\hline
\end{tabular}

Table 5: Factors discouraging from reporting.

\begin{tabular}{|l|l|}
\hline Factors & Percentage \\
\hline Lack of time to report ADR & 38.8 \\
\hline $\begin{array}{l}\text { Difficult to decide whether ADR has } \\
\text { occurred or not }\end{array}$ & 35.5 \\
\hline $\begin{array}{l}\text { A single unreported case may not } \\
\text { affect ADR database }\end{array}$ & 17.7 \\
\hline $\begin{array}{l}\text { No remuneration } \\
\text { Fear of action against person } \\
\text { reporting }\end{array}$ & 20 \\
\hline Don't know where and how to report & 71.11 \\
\hline
\end{tabular}

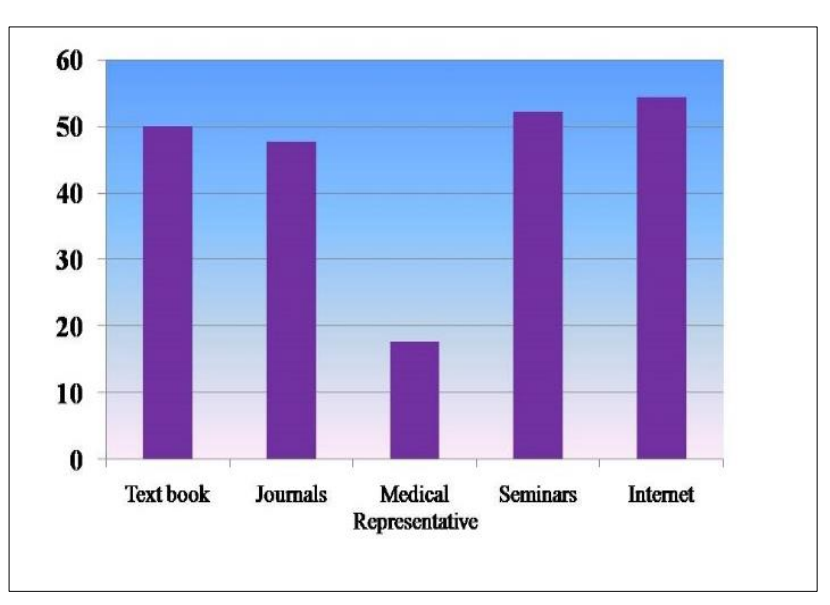

Figure 1: Source of information on ADR.

\section{DISCUSSION}

Present study was a questionnaire-based study which included family physicians of Surat city of Gujarat. Questionnaire forms (200) were distributed out of these only 120 filed forms received back i.e. response rate in our study was $62 \%$ which was similar to study by Desai et al but study done by Reddy et $\mathrm{al}^{5}$ response was $90 \%$. $^{6}$

About 93\% doctors were aware about the necessity of reporting in our study similar results obtained by Hardeep et al and Lin et al but in study of Batman et al it was different. $^{7-9}$

In the present study, $93 \%$ family physicians agreed that reporting is necessary and in $92 \%$ agreed that it increases safety of patients. Similar results were seen in the study by Upadhyay et al $93.07 \%$ and $92.08 \%$ respectively. ${ }^{10}$

In our study, practitioners have knowledge about pharmacovigilance (Table 1) but they don't practice (Table 3 and 5). Chatterji et al observed similar results while Updhyay observed poor knowledge and poor practice. $^{11}$

Similar with the findings of Bharatn et al, in our study, only $30 \%$ doctors were aware of any helpline for reporting ADR. ${ }^{12}$

In our study, $19 \%$ respondent stated that they have reported ADR previously but Upadhyay et al observed that $7.9 \%$ doctors reported ADR previously. ${ }^{10}$

In the present study, $71.11 \%$ doctors don't know how and where to report an ADR similar results i.e. $70 \%$ observed by Radhakrishnan et al. ${ }^{13}$

In our study, $38.8 \%$ practitioners opined that lack of time is the cause of under reporting of ADR which is similar by study conducted by Veleno et al. ${ }^{14}$ 
The limitation of the study was attrition in the sample size, only $62.5 \%$ family physician responded to questionnaire out of these incomplete responses were excluded from the study so the sample size became smaller. The further study is needed with bigger sample size.

\section{CONCLUSION}

The family physicians of Surat have adequate knowledge about pharmacovigilance and aware that ADR should be reported. However, most of them have not reported any ADR due to various reasons.

\section{Funding: No funding sources}

Conflict of interest: None declared

Ethical approval: The study was approved by the Institutional Ethics Committee

\section{REFERENCES}

1. World Health Organization: International drug monitoring; the role of hospital. In technical report series no. 425, Geneva, Switzerland: World Health Organization. 1966;1-25.

2. Brewer T, Colditz GA. The post marketing surveillance and adverse reactions; The current perceptive and future needs. JAMA. 1999;281(9):8249.

3. Lobo MGADA, Pinheiro SMB, Castro JGD. Adverse drug reaction monitoring: support for pharmacovigilance at a tertiary care hospital in Northern Brazil. BMC Pharmacol Toxicol. 2013;14:5.

4. Muraraiah S, Rajarathna K, Sreedhar D, Basavalingu D. A questionnaire study to assess the knowledge, attitude and practice of Pharmacovigilance in a paediatric tertiary care centre. J Chem Pharm Res. 2011;3(6):416-22.

5. Reddy V, Pasha S, Rathinavelu M, Reddy Y. Assessment of Knowledge, Attitude and Perception of Pharmacovigilance and Adverse Drug Reaction (ADR) Reporting among the Pharmacy Students in South India. J Pharm Biol Sci. 2014;9:34-43.

6. Desai CK, Iyer G, Panchal J, Shah S, Dikshit RK. An evaluation of knowledge, attitude, and practice of adverse drug reaction reporting among prescribers at a tertiary care hospital. Perspect Clin Res. 2011;2(4):129-36.
7. Singh H, Bajaj J, Kumar R. A Survey on the Knowledge, Attitude and the Practice of PharmacovigilanceAmong the Health Care Professionals in a Teaching Hospital in Northern India. J Clin Diagn Res. 2013;7:97-9.

8. Qing L, Su-min Z, Hua-ting C, Shi-ping F, Xin Y, Dong $\mathrm{L}$, et al. The awareness and the attitudes of the healthcare professionals in Wuhan, China about/towards the reporting of adverse drug reactions. Chinese Med J. 2004;117(6):856-61.

9. Belton KJ, Lewis SC, Payne S, Rawlins MD, Wood SM. An attitudinal survey on the adverse drug reaction reporting by the medical practitioners in the United Kingdom. Br J Clin Pharmacol. 1995;39(3):223-6.

10. Upadhyaya HB, Vora MB, Nagar JG, Patel PB. Knowledge, attitude and practices toward pharmacovigilance and adverse drug reactions in postgraduate students of Tertiary Care Hospital in Gujarat. J Adv Pharm Technol Res. 2015;6(1):29-34.

11. Chatterjee S, Lyle N, Ghosh S. A survey of the knowledge, attitude and practice of adverse drug reaction reporting by clinicians in eastern India. Drug Saf. 2006;29:641-2.

12. Bharathan B, Raju N. A Survey about the Knowledge, Attitude and Practice of Adverse Drug Reaction Reporting Among Doctors in Bangalore City. Sixth Annual Conference of the Society of Pharmacovigilance (India). Kurupanidhi College of Pharmacy, Bangalore, India. 2006.

13. Radhakrishnan R, Vidyasagar S, Varma DM. An educational intervention to assess knowledge attitude practice of pharmacovigilance among Health care professionals in an Indian tertiary care teaching hospital. Int J Pharm Tech Res. 2011;3:678-9.

14. Vallano A, Cereza G, Pedròs C, Agustí A, Danés I, Aguilera C, Arnau JM. Obstacles and solutions for spontaneous reporting of adverse drug reactions in the hospital. Br J Clin Pharmacol. 2005;60(6):653-8.

Cite this article as: Saxena K, Srivastava SK. Assessment of knowledge, attitude and practice of reporting of adverse drug reaction among family physicians in Surat city. Int J Basic Clin Pharmacol $2021 ; 10: 820-3$. 